Dr Ištvan Bodolo, dipl. ing.

stalni sudski veštak

predsednik Udruženja veštaka „Vojvodina”

\title{
VEŠTAČENJE UZ UPOTREBU SOFTVERA ZA SIMULACIJU SAOBRAĆAJNIH NEZGODA - VERIFIKACIJA*
}

\begin{abstract}
SAŽETAK: U radu je izvršen kratak prikaz tri pojedinačna eksperimenta sa ukupno četiri sudara koja su poslužila da se verifikuju mogućnosti i potvrdi tačnost upotrebe softvera za simulaciju sudara Virtual Crash 2.2 za potrebe sudske prakse. Eksperimente realnih sudara je izveo gorenavedeni naslov tokom 2008. godine i predstavljaju privatni - ne od strane institucija, izvedeni i pre svega prvi istraživački poduhvat iz oblasti saobraćajnih nezgoda (SN) u Srbiji. Cilj je bio dokazati primenljivost upotrebe softvera za simulaciju SN u sudskoj praksi Republike Srbije. Rad je multimedijalan, jer se celovita informacija u vezi teme može dobiti na osnovu uporednih istovremenih video snimaka sudara koji se nalaze na sajtu www.vestacenja.co.rs

Ključne reči: Virtual Crash, Saobraćajne nezgode (SN), simulacije, eksperimenti realnih sudara, sudska praksa
\end{abstract}

\section{UVOD}

Veštačenje predstavlja tehničku pomoć sudu baziranu na prirodnim zakonima fizike, stručnim znanjima i veštinama izvedenim na bazi prethodno obezbeđenih materijalnih tragova. Svaka od stručnih disciplina iz oblasti veštačenja, koje se pojavljuju u sudskoj praksi beleže stalnu difuziju naučnih znanja u praksu koja je, čini se još snažnije potpomognuta podrškom iz rubnih oblasti, ponajpre kompjuterizacijom i razvojem brojnih softvera. Unazad oko 9 godina gorenavedeni naslov koristi softvere za

* Rad primljen: 03. 09. 2009. godine. 
simulaciju saobraćajnih nezgoda i tek je pre oko godinu dana počelo osetnije interesovanje veštaka za analizu sudara pomoću licenciranih softvera - više iz okolnih zemalja a ipak manje iz Srbije.

U toku višegodišnje upotrebe softvera uočeno je da se uobičajeno postojećoj skepsi, sumnjičavosti i stalnom proveravanju elemenata veštačenja mora dodati i sumnja u upotrebljivost savremenih sredstava, pre svega baziranih na nepoznavanju načina rada i metodološkog pristupa za upotrebu softvera za simulaciju, najpre Virtual Crash kao trenutno najsavremenijeg sredstva ove vrste. Sudskoj praksi, pre svega advokatima, nije poznato kako se izračunava sudarna brzina kretanja vozila i ostalih učesnika u sudaru kao i dinamike kretanja vozila.

Široj praksi nisu poznate mogućnosti softvera što je veoma važno jer se npr. ne može prihvatiti navodno određivanje mesta kontakta ususretnih vozila oko razdelne linije samo na bazi softvera, kao što se ne može prihvatiti ni brzina kretanja pešaka veoma pozne životne dobi koji trči brže od gornjih granica mladih i to samo zato što „to tako kaže softver”. Kada sud u toku vremena, zamoren brojnim veštačenjima naruši princip jednakog ranga svih veštačenja (dajući apsolutnu prednost poslednjem veštačenju), onda postaje posebno značajno da državne institucije (pojedni fakulteti iz uže Srbije i zavodi) nekada praktično arbitriraju na ovako neprihvatljiv način ishodujući presude, pa čak i koristeći nelicencirane softvere.

\section{CILJ}

Prvi cilj rada je kratak opis načina izrade jedne simulacije sudara.

Drugi cilj je predlog metodološkog pristupa za izradu veštačenja na način da bude jasan, lak i brz za čitanje kao i lako i efikasno proverljiv i pešačkim (tradicionalnim) načinom rada.

Treći cilj je verifikacija softvera Virtual Crash potvrđivanjem njegove tačnosti tako što će očigledno izvesti eksperiment realnih sudara i oni potvrditi uz upotrebu softvera.

Četvrti cilj je kratak komentar forme i sadržaja mišljenja u veštačenju.

\section{HIPOTEZA}

U radu će biti izvršen kratak opis konačnih rezultata sledećih eksperimenata:

- Nalet gradskog autobusa na bicikl sa lutkom pri malim brzinama

- Nalet gradskog autobusa na putnički automobil pri malim brzinama

- Nalet putničkog automobila na bicikl sa lutkom pri velikim brzinama

- Nalet gradskog autobusa na putnički automobil pri velikim brzinama

Opis, zbog ograničenog prostora, nije kompletan. Da bi se postigao celovit i pre svega očigledan dokaz, čitalac mora da pregleda uporedne i 
jednovremene video filmove na sajtu www.vestacenja.co.rs, na kojima se na jednom ekranu jednovremeno kreću učesnici u sudaru snimljeni video kamerama i, iz istog položaja izvednom simulacijom.

\section{KRATAK OPIS IZRADE JEDNOG VEŠTAČENJA SN}

Veoma često se u praksi ističe da veštak "ubacuje" neke podatke u računar i da onda softver ,izbacuje" neki rezultat koji nakon toga veštak zastupa i „brani” na sudu. Tako se sugeriše da je narušen princip opšte dostupnosti rezultata veštačenja što direktno dovodi u sumnju i da je narušen princip objektivnosti veštaka i veštačenja i direktno dovodi u sumnju novi princip (unutrašnje uverenje veštaka).

Proces izrade ma kog veštačenja se može determinisati sledećim koracima:

1. korak: Kreiranje - crtanje detaljnog plana zone mesta sudara sa generisanjem reljefa (kanali, ivičnjaci, poledica, bandere, ograde, objekti...) sa kotama tragova iz Zapisnika o uviđaju.

2. korak: Definisanje učesnika u sudaru (vozila, tela...) sa pripadajućim masama i dimenzijama.

3. korak: „Pešačko” postavljanje učesnika (vozila pre svega) u sudarni položaj kao i njihov međusobni položaj u primarnom kontaktu. To znači da se mesto kontakta, osim u retkim slučajevima, ne može odrediti isključivo upotrebom softvera (čisto teorijski bi moglo). Mesto kontakta se uvek određuje na bazi materijalnih tragova fiksiranih na licu mesta (zaparotine, tragovi kočenja, forma deformacija...) tj. pešačkim radom ili trasološkim veštačenjem.

4. korak: Inicijalno zadavanje brzine kretanja vozila tako da se postigne usmerenje oba vozila ili učesnika ka zaustavnim položajima posle sudara.

5. korak: Nakon toga se pristupa finijem podešavanju sudara, tako da se postignu tačniji zaustavni položaji vozila postizanjem realnih parametara samog sudarnog procesa, od kojih su najvažniji EES (veoma sličan $\Delta \mathrm{V}$ iz pešačkog rada), koeficijenta sudara $\mathrm{k}$, koeficijenta češanja $\mu$, visine centra sudara i položaja sudarne ravni u momentu najveće kompresije i rotacije vozila). Opisani metod je metod pogreške i pokušaja koji se ocenjuju u realnom vremenu izrade $i$ obično ih ima više stotina a ponavljaju se sve dok se ne dobiju dovoljno tačni i usaglašeni parametri sudara koji se potvrđuju vizuelnim pokretnim slikama.

6. korak: Nakon postignutog prihvatljivog, pešačkim radom proverljivog i obrazloživog rezultata pristupa se izradi vremensko-prostornog rasporeda pomoću kimenatičkih slika uzastopnih sinhronizovanih položaja vozila pre i neposredno pre sudara. Položaji, koje veštak definiše, su u direktnoj vezi sa radnjama, kao skupom psihičkih odnosa učinioca prema delu koji se izražavaju u svesti i volji. To je uvod u odnose koje veštak 
želi da prikaže na relaciji dozvoljeno-nedozvoljeno, propisno-nepropisno, pravilno-nepravilno. Sve radi postupaka koji znače oblike vinosti: eventualni umišljaj, svesni ili nesvesni nehat, kao pripremi za formiranje mišljenja u veštačenju koji je tehnička interpretacija pravnog aspekta saobraćajne nezgode sa izvorištem primarno u delu a tek sekundarno u formulaciji optužnice.

Prikazani koraci moraju imati podlogu i u rezultatima pešačkog rada u bitnom, ako su oba metoda izrađena na istim - realnim osnovama. Simulacioni je uverljiviji, jasniji, složeniji za izradu, vizuelno potkrepljiv, i bitno duži za izradu.

U sudovima EU, uobičajeno priznaje se 2,5 sata rada više kada se veštačenje izrađuje pomoću softvera. Iskustvo autora je da je toliko, za obračun cene veštačenja, priznato vreme najmanje realno - često je duže.

\section{METODOLOŠKI PRISTUP VEŠTAČENJU SN SA ASPEKTA PROVERLJIVOSTI}

Mogućnosti prikaza rezultata upotrebe softvera za simulaciju sudara Virtual Crash je veoma velika. Autor smatra stručno nekorektnim ispostavljanje listinga rezultata na oko 4-5 stranica prepunoj skraćenica čiji značaj najčešće ni samim veštacima nije do kraja jasan. Dovoljan je prikaz osnovnog prozora sudarnog procesa koji sadrži sve potrebne elemente da bi se pešačkim radom proverila sudarna brzina uvek za kraće vreme od jednog minuta. Prikazan prozor sadrži podatak EES koji se može zameniti sa $\Delta \mathrm{V}$ iz pešačkog rada i na osnovu zaustavnog puta nakon sudara upotrebom poznate kinematičke jednačine proveriti dobijena sudarna brzina.

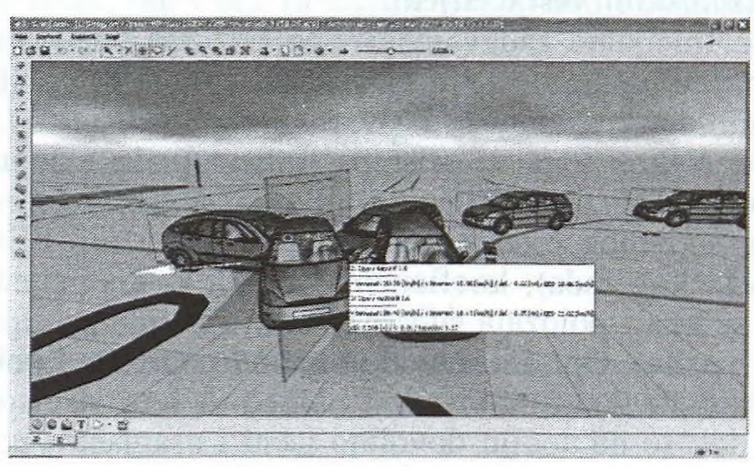

Odnosno, da bi se proverila brzina dobijena simulacijom potrebno je iz priloženog prozora očitati EES za svako vozilo i izračunati brzinu pomoću uobičajene formule: $V_{n} \geq \sqrt{2 \cdot a \cdot S+\Delta V_{1}^{2}}$, za šta je potrebno manje od minuta.

Prethodna dva naslova upućuju na održivost principa opšte dostupnosti rezultata veštačenja, principa objektivnosti veštaka i veštače- 
nja i principa unutrašnjeg uverenja veštaka, jer su rezultati transparentni i lako i u bitnom brzo i lako proverljivi.

\section{VERIFIKACIJA SOFTVERA VIRTUAL CRASH UZ POMOĆ IZVEDENIH EKSPERIMENATA REALNIH SUDARA}

Centar za veštačenja i procene doo je u toku 2008. godine u prisustvu predstavnika pravosudnih organa, tužilaštva, policije i Fakulteta tehničkih nauka iz Novog Sada i Saobraćajnog fakulteta iz Budimpešte i autora softvera Virtual Crash... izveo niz eksperimenata realnih sudara pomoću kojih je pored stečenog novog iskustva u primeni softvera dokazao njegovu primenjivost i tačnost.

- Nalet gradskog autobusa na bicikl sa lutkom pri malim brzinama

Forsirano kočeni gradski autobus je naleteo na biciklistu u sustizanju naletnom brzinom od $34,5(\mathrm{~km} / \mathrm{h})$ i odmah potom na Zastavu 101 brzinom od $32,5(\mathrm{~km} / \mathrm{h})$. Brzina je proverena $\mathrm{i}$ izmerena tahografskim listićem, policijskim radarom Fama Laset III pro i akcelerometrom XL metar vlasništvo autora. Nakon sudara izvršen je detaljan uviđaj, fiksirani su svi relevantni tragovi i izvedena je simulacija sudara koja je u potpunosti potvrdila validnost sudara - vidi filmove na www.vestacenja.co.rs.




- Nalet putničkog automobila na bicikl sa lutkom pri velikim brzinama i gradskog autobusa na Reno 4

$\mathrm{Za}$ potrebe izvođenja sudara autor je izradio antropometrijsku lutku realne težine, sa svim zglobovima koji se mogu pokretati isto onako kako se pokreće ljudsko telo. Nabavljen je Renault 4 koji je brzinom od 54 $(\mathrm{km} / \mathrm{h})$ naleteo na biciklistu a nakon toga autobus brzinom od $55(\mathrm{~km} / \mathrm{h})$ na Reno 4. Posetioci sa Saobraćajnog fakulteta iz Budimpešte su snimili sudare brzim kamerama koji snimci su gotovo identični sa usporenim snimcima mehanizna nastanka sudara koji je izveden upotrebljenim softverom. Lutka i bicikl a kasnije autobus i Reno 4 su se kretali na identičan način i odbačeni su tačno onako kako „pešačke” jednačine i dijagrami pokazuju - vidi filmove na www.vestacenja.co.rs

Slede neki od snimaka brzih kamera:


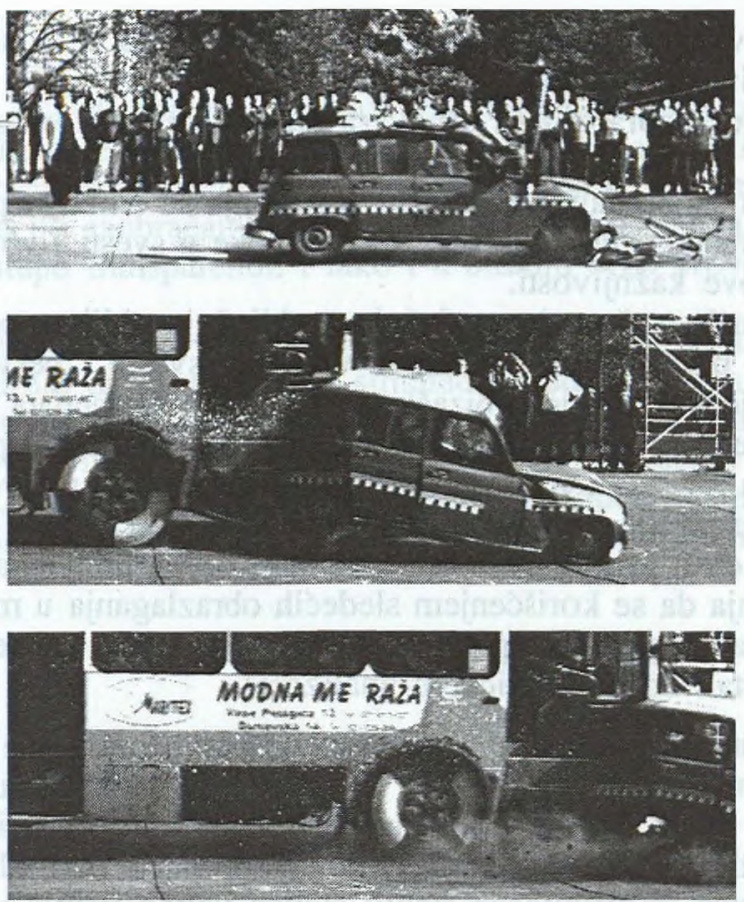

\section{MIŠLJENJE U VEŠTAČENJU SN}

Nakon tehničkih parametara koji se nalaze u delu nalaza saobraćajno-tehničkog veštačenja sledi mišljenje koje ne obavezuje sud i koje od strane veštaka kao lica koje nije stručno za pravo sagledavanjem celine slučaja, zadire u pravnu sferu.

U praksi, veštaci iskazuju svoje mišljenje na veoma različite načine, od veoma šturih do veoma detaljnih koji više liče na čisto tehnički zaključak.

Autor je mišljenja da je to posledica načina postanka veštakom (ili lako ili nikako), nepostojanja prethodne stručne (pravničke) obuke i nepostojanja zahteva suda, u tom pogledu.

Takođe, u praksi sudije (parnične i krivične) imaju veoma različite zahteve prema mišljenju.

Nekima odgovara šturo mišljenje a drugima detaljno.

Mišljenje, prvenstveno u krivičnom postupku mora da proistekne nezavisno od optužnice ali i da podržava norme koje proističu iz optužnice - ako je optužnica pogodila suštinu dela a veštačenjem se to isto potvrdilo. Opis dela u optužnici je često veoma opšt i ne opisuje detaljno i konkretno radnju opisanu u ZOBS ili pripadajućem pravilniku. Od optu- 
žnice preko veštačenja svih struka do presude mora se postići objektivni identitet u bitnom stepenu. akti.

Radnje u saobraćaju su osnov za kažnjivost i one su svesni i voljni

Rezultat saobraćajno-tehničkog veštačenja su tehnički parametri koje u mišljenju veštak treba da svede na postupke u svesti i volji u vezi radnje kao osnove kažnjivosti.

To iz razloga što vinost (krivica) uključuje oblike postupaka: umišljaj i nehat, prvenstveno eventualni umišljaj, svesni i nesvesni nehat.

Mišljenje veštaka je proizašlo iz tehničkih elemenata ali se raznim saznajnim metodama (dedukcija, indukcija, generalizacija, apstrakcija analiza i sinteza...) svodi na kvalifikacije bliske prepoznatljivosti od strane pravne struke prema oblicima vinosti (umišljaj i nehat).

Budući da u prirodi veštačenja ne stoji ocena umišljaja i nehata, autor je mišljenja da se korišćenjem sledećih obrazlaganja u mišljenju može sa tehničke tačke gledišta uputiti na oblik vinosti do koga je saobraćajno-tehnički veštak došao tehničkom analizom:

- Eventualni umišljaj: ...svesno prihvatio nastupele posledice; bi svestan da usled njegovog činjenja ili nečinjenja može nastupiti zabranjena posledica ali je pristao na njeno nastupanje... (postoji i svest i volja koja je pokatkad i jača od svesti, tj. ima se svesti o delu ali se želi duga posledica. Ovde je artikulisan slabiji stepen voljne radnje od želje i htenja).

- Svesni nehat: ...bio svestan da uslèd njegovog činjenja ili nečinjenja može nastupiti posledica ali je nerealno, olako i pogrešno procenio da radnjom koju je izveo ona neće nastupiti... (postoji i volja i svest koja je jača od volje do nivoa da u potpunosti izostaje voljni element jer je bio uveren da će učesnik u saobraćaju moći da otkloni posledicu).

- Nesvesni nehat: ...nije bio svestan mogućnosti nastupanja zabranjene posledice iako je prema okolnostima i svojim ličnim svojstvima bio dužan i mogao biti svestan nastupele mogućnosti... ili ....ima eventualni doprinos... (nije postojala ni svest ni volja ali je mogao i bio dužan da takvu - potrebnu svest ima).

U predmetima iz parničnih postupaka, mišljenje je autora, potrebno je čvršće strukturiranje mišljenja dodatnim obrazlaganjima pomoću brojnih načela ponašanja u saobraćaju (poverenja, nepoverenja...) i modela vožnje (defanzivna, najmanjeg rizika, nepoverenja, ograničene pouzdanosti...) čija je funkcija da posluže kao kriterijum za bolju ocenu postupaka.

Načela ponašanja i modeli vožnje same po sebi nisu osnov za određivanje krivice nego su merila odnosa u ponašanju što je dodatna pomoć u oceni stepena doprinosa učesnika u saobraćajnoj nezgodi posebno u predmetima građanske parnice. 


\section{ZAKLJUČAK}

Autor je u prikazanom radu dokazao održivost principa opšte dostupnosti rezultata veštačenja, principa objektivnosti veštaka i veštačenja i principa unutrašnjeg uverenja veštaka prilikom upotrebe savremenih softvera za simulaciju saobraćajnih nezgoda. Rezultati su, zahvaljujući metodološkom pristupu transparentni i lako i u bitnom brzo proverljivi pešačkim radom.

Simulacije sudara iz izvedenih sopstvenih eksperimenata su nedvosmisleno dokazale da je softver za simulaciju sudara Virtual Crash pouzdano sredstvo za analizu sudara i da se u slučaju transparentnog i na proverljiv način prikazanog sudara može koristiti u sudskoj praksi.

Na kraju, autor je opisao značaj čvršćeg strukturiranja mišljenja saobraćajno-tehničkog veštačenja sa ostalim procesnim radnjama. 